\title{
Gradual Changes to Discipline: A Case Study of Punish- ment Records and Corporal Punishment in Three Schools in Finland After the 1872 School Order Act
}

\author{
Karoliina Puranen \& Matti Roitto
}

\begin{abstract}
Punishment and violence in the history of education have been covered in numerous scholarly works, but most of them have relied heavily on what might be considered normative sources such as regulations, legislation, other studies in the history of education, various instructions, manuals, and guidebooks. The history of education in Finland, as elsewhere, would have us believe that punishment practices in general changed drastically, and that corporal punishment in particular had been dropped by the late nineteenth and early twentieth centuries, as proscribed in secondary schools by the School Order Act of 1872. We argue, however, that this was not always the case, especially when certain empirical sources that have often been overlooked — such as school punishment records-are taken into account. We use these sources to explore whether punishments in general, and corporal in particular, continued to be administered all the same after 1872. Our hypothesis is that the "cultural shift" regarding this issue was more gradual and complex than previously assumed. The administering of punishments, corporal or otherwise, clearly continued after the legislation had changed, regardless of whether contemporary educationalists were recommending other means of managing pupil behaviour. For instance, it remained culturally acceptable, at least for secondary schools, to "chastise" pupils (to send them home for corporal punishment). Our findings add to the existing knowledge on punishment practices and provide valid grounds for re-evaluating research on the matter.
\end{abstract}

Keywords • school, discipline, violence, punishment, history, Finland

\section{Introduction}

This exploratory article aims to add to our existing knowledge of the complex history of discipline and punishment practices in schools. Previous studies on the subject have mostly concentrated on the more abstract regulation aspects of discipline and punishment. ${ }^{1}$ These works have relied very heavily on the use of more norma-

This article is based on the archival work and findings covered in the master's thesis of Karoliina Puranen, Kiltit tytöt, vilkkaat pojat?: Sukupuoli ja koulukuri 1800-1900-lukujen vaihteen oppikouluissa (Jyväskylä: University of Jyväskylä, 2015). http://urn.fi/URN:NBN:fi:jyu-201506012117, but the analytical focus here is on the relation between punishments and violence. The authors wish to thank Heli Valtonen and Satu Matikainen and the two anonymous referees for their valuable insights on the article manuscript.

1 For more on punishment as a last resort, see e.g. Mika Ojakangas, Lapsuus ja auktoriteetti: Pedagogisen vallan historia Snellmanista Koskenniemeen (Helsinki: Tutkijaliitto, 1998); Leevi Launonen, Eettinen kasvatusajattelu suomalaisen koulun pedagogisissa teksteissä 1860-luvulta 1990-luvulle (Jyväskylä: University of Jyväskylä, 2000); Joakim Landahl, “The Eye of Power(-lessness): On the Emergence of the Panoptical and Synoptical Classroom" History of Education 42, no. 6 (2013).

Karoliina Puranen is a Doctoral Student in Finnish History at the Department of History and Ethnology, University of Jyväskylä, Finland.

Email: karoliina.n.puranen@jyu.fi

Matti Roitto is a Postdoctoral Researcher in General History at the Department of History and Ethnology, University of Jyväskylä, Finland.

Email:matti.roitto@jyu.fi 
tive sources, which may have overlooked the full extent to which the ideas being discussed were actually employed in everyday school life in the past. Indeed, by grounding our theory and basing our explorative empirical analysis on a case study that uses the punishment record ${ }^{2}$ of secondary schools, we address this aspect of the everyday practice of punishment in schools that previous research has overlooked. It also answers calls for a long-term, historical and critical study of education (e.g., Rappleye and Cowen). ${ }^{3}$

In the late nineteenth and early twentieth centuries, the mass education system in "Finland" ${ }^{4}$ was only just beginning to follow the Prussian model ${ }^{5}$ already in place in other Nordic states ${ }^{6}$. Teachers were usually prominent figures in the immediate community but norms, punishment practices, and contexts varied greatly within the profession, and attempts were being made to secularise and regulate what education there was. $^{7}$

By exploring the case level, this article also looks at the extent to which such new educational regulations were carried out in practice. One such regulation, which would form the normative basis for all disciplinary measures ${ }^{8}$ in Finnish secondary schools in the early twentieth century, was the School Order Act of 1872. It in-

2 Schools are still required to list issued punishments in Finland: see Pirjo Vehkamäki, Matti Lahtinen and Anne Tamminen Dahlman, Julkisuus ja tietosuoja opetustoimessa: Opas koulujen ja oppilaitosten käyttöön (Tampere: Opetushallitus, 2013), 75.

3 Robert Cowen, "Comparing Futures or Comparing Pasts?, Comparative Education 36, no. 3 (2000), 340; Jeremy Rappleye, Educational Policy Transfer in an Era of Globalization: Theory-HistoryComparison, Komparatische Bibliothek 23 (Frankfurt am Main: Peter Lang, 2012), 2-4.

4 In this article we use "Finland" as a descriptive term, as independent Finland existed only from 1917 on.

5 John Strömberg, “Oppikoulun laajentuminen ja yhtenäistyminen,” in Valistus ja koulunpenkki: Kasvatus ja koulutus Suomessa 1860-luvulta 1960-luvulle, ed. Anja Heikkinen and Pirkko Leino-Kaukiainen (Helsinki: Suomalaisen Kirjallisuuden Seura, 2011); Saara Tuomaala, "Kamppailu yhteisestä koulusta ja oppivelvollisuudesta," in Valistus ja koulunpenkki: Kasvatus ja koulutus Suomessa 1860-luvulta 1960-luvulle, ed. Anja Heikkinen and Pirkko Leino-Kaukiainen (Helsinki: Suomalaisen Kirjallisuuden Seura, 2011); Aimo Halila, Suomen kansakoululaitoksen historia 1: Kansanopetus ennen kansakoulua ja kansakoululaitoksen synty (Porvoo, Helsinki: WSOY, 1949); Mette Buchardt, Pirjo Markkola and Heli Valtonen, "Introduction: Education and the Making of the Nordic Welfare States," in Education, State and Citizenship, ed. Mette Buchardt, Pirjo Markkola, and Heli Valtonen (Helsinki: University of Helsinki, 2013).

6 Ola Svein Stugu, "Educational Ideals and Nation Building in Norway 1840-1900," in Nordic Lights: Education for Nation and Civic Society in the Nordic Countries, 1850-2000, ed. Sirkka Ahonen and Jukka Rantala (Helsinki: Finnish Literature Society 2001); Marja Jalava, "Kansanopetuksen suuri murros ja 1860-luvun väittely kansakoulusta," in Valistus ja koulunpenkki: Kasvatus ja koulutus Suomessa 1860-luvulta 1960-luvulle, ed. Anja Heikkinen and Pirkko Leino-Kaukiainen (Helsinki: Suomalaisen Kirjallisuuden Seura, 2011); Bengt Sandin, Hemmet, gatan, fabriken eller skolan: Folkundervisning och barnuppfostran i svenska städer 1600-1850 (Lund: Arkiv, 1986).

7 Sirkka Ahonen, "Millä opeilla opettajia koulutettiin?" in Valistus ja koulunpenkki: Kasvatus ja koulutus Suomessa 1860-luvulta 1960-luvulle, ed. Anja Heikkinen and Pirkko Leino-Kaukiainen (Helsinki: Suomalaisen Kirjallisuuden Seura, 2011); Ulla Johansson and Christina Florin, “The Trinity of State, Church and School in 19th Century Sweden," in Polish and Swedish Schools in the 19th and 20th Centuries: A Historical Study, ed. Ryszard Kucha and Ulla Johansson (Lublin: Maria Curie-Sklodowska University Press 1995); Lennart Tegborg, Folkskolans sekularisering 1895-1909: Upplösning av det administrativa sambandet mellan folkskola och kyrka i Sverige (Uppsala/Lund: Föreningen för undervisningshistoria, 1969).

8 See for instance Launonen (2000), Ojakangas (1998), Esp. Kyösti Kiuasmaa, Oppikoulu 1880-1980: Oppikoulu ja sen opettajat koulujärjestyksestä peruskouluun (Oulu: Pohjoinen, 1982). 


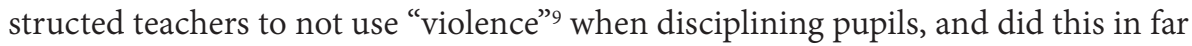
stronger terms than those used in earlier legislation (1843). These had previously stipulated that a teacher was allowed to use "milder forms of corporal punishment," while headmasters were able to use "stricter methods of corporal penalties." ${ }^{10}$ This meant that, until 1872 , both teachers and headmasters were able to use a degree of violence to enforce discipline and punish offenders. More normative sources from this period, and historical works based on them, indicate that this position was also endorsed by many educationalists at the time - and not just in Finland. ${ }^{11}$ Our hypothesis is that the act of 1872 heralded a more gradual change in punishment culture than previous literature would suggest, that is borne out by our focus on school punishment records themselves. Although this idea might seem like common sense, it has never been explicitly addressed in previous research.

\section{Previous studies}

The history of education is a broad field, and school punishment practices have received much attention. There are even studies that focus on just one particular method of punishment, such as "the rod," for instance, which was often the tool of punishment used most by most educators. ${ }^{12}$ Or then there was "incarceration," 13 particular punishment method used in Swedish and Finnish secondary (and even tertiary) education, that Swedish historian Björn Norlin has focused on. ${ }^{14}$ Norlin's research calls into question whether this might also be counted as a form of violence too. Indeed, even if it was not seen as so by contemporaries, the coercive aspect of denying pupils freedom could nowadays be construed as such, in so far as it is forcing someone to do something (or limiting them) against their will. Unlike others, Norlin makes it clear that the issues relating to punishment and violence are far from simple, and are implicitly caught up in the issue of anachronism. ${ }^{15}$

9 We recognise that the concept of "violence" differs greatly according to era. Considering corporal punishment as violence is useful for this article's research position, based as it is on legislative sources, forbidding corporal punishment in schools. Corporal punishment at home was not legally treated as violence in the same way though. This illustrates just how complex the matter was when all contexts are taken into account.

10 Until, 1843, corporal punishment was legal in Finnish secondary schools: Hans Kejserliga Majestäts Nådiga Gymnasie- och Skol-Ordning får Storfurstendömet Finland (henceforth HKMNG), November 6,1843. Previous works point out that corporal punishment was being dropped already in 1832 (see Ojakangas 1998), however, this particular change was not in the legislation for schools (indeed, the School Act of 1856 did not change punishment regulations), but in a statute issued for doctors (Hans Kejserliga Majestäts Nådiga Instruction för Provincial-Läkarene i Finland, January 17, 1832). In fact, from 1872 to 1972, one of the main punishments enshrined in the rules was karsseri (school jail). For more on punishment legislation: HKMNG, November 6, 1843; HKMNG, March 31, 1856; Keisarillisen Majesteetin Armollinen Koulujärjestys Suomen Suuriruhtinaanmaalle (henceforth KMAKS), August 8, 1872.

11 Cf. Ojakangas (1998); Landahl (2013); Launonen (2000).

12 Regarding corporal punishments, e.g. Eric Margolis and Sheila Fram, "Caught Napping: Images of Surveillance, Discipline and Punishment on the Body of the Schoolchild," History of Education 36, no. 2 (2007).

13 "School jail," or literally "incarceration" (karzer in German), translates as karsseri in Finnish. It was only in the 1970s when this practice was banned in Finnish secondary schools, Kiuasmaa (1982), 128.

14 Björn Norlin, "School Jailhouse: Discipline, Space and the Materiality of School Morale in Early-Modern Sweden," History of Education 45, no. 3 (2016). For instance, Norlin mentions that a pupil in school jail might have been left without a meal or drink as well.

15 Norlin addresses the harshness of practices such as school jail, detention, and isolation, even though they were not considered forms of violence by staff at the time. 
Many earlier studies in educational history have drawn particularly from the ideas of Michel Foucault (1977), who has pointed to the emergence of discipline as a form of power in some of the first "hospitals" and schools of the early modern era. ${ }^{16}$ In the Finnish context, Mika Ojakangas has examined discipline in Finnish schools (1860-1950) from such a Foucauldian perspective. His research has opened the topic up greatly and garnered much well-earned attention in Finland. According to Ojakangas, the primary aim of education was to instil moral values in pupils that would serve them throughout life to keep learning, and the only way to do this was to discipline them according to school rules. Discipline was thus not just a tool of education, but also one of its key subjects. ${ }^{17}$ The notion of conditioning boys in this way for later life has, for instance, spawned a wealth of studies in Finnish and Swedish. ${ }^{18}$ Ojakangas also goes on to suggest that the punishments themselves were only one small part of a wider disciplinary system throughout schools, but in this article, we focus only on the systems of punishment used in the particular schools in question. This is done to present a contrast with previous research based on more normative sources.

Educationalists from the late nineteenth or early twentieth centuries suggested that punishment should not be the norm in everyday school life. Only in exceptional cases of bad behaviour should teachers resort to actual punishment, and even then, it should go no further than a punitive gaze, or issuing detention. Corporal punishment was seen as the last recourse for teachers that had failed in their duty. ${ }^{19} \mathrm{Un}$ fortunately, these views, to be found not only in Ojakangas' work, but also in more contemporary studies, ${ }^{20}$ have been taken at face value, when they could clearly be better contextualised with regard to the everyday level of punishment actually practised in schools, but this is understandable since these studies are theory-driven, and so research is necessarily limited in detail when addressing such a wide timeframe and theme.

Another important example of theory-driven research is that of Swedish educationalist, Joakim Landahl, who has explored the significance of softer punishment methods in Swedish schools during the twentieth century in terms of the Foucauldian "panopticon," and Thomas Mathiesen's “synopticon.” Like Ojakangas, Landahl argues that school discipline for whole class teaching in the late nineteenth century

16 Michel Foucault, Discipline and Punish: the Birth of the Prison (London: Penguin Books, 1977). Although power as a theoretical concept represents an important perspective on the topic, it is not our focus here.

17 Ojakangas (1998), 23-26, 35-36, 74-78.

18 Anders Ahlbäck, Soldiering and the Making of Finnish Manhood: Conscription and Masculinity in Interwar Finland, 1918-1939 (Turku: Åbo Akademi University, 2010); Esbjörn Larsson, Från adlig uppfostran till borgerlig utbildning: Kungl. Krigsakademien mellan åren 1792 och 1866 (Uppsala: Uppsala University, 2005); Henrik Meinander, Towards a Bourgeois Manhood: Boys' Physical Education in Nordic Secondary Schools 1880-1940 (Helsinki: The Finnish Society of Sciences and Letters, 1994).

19 Ojakangas (1998), 55-63.

20 Google scholar alone reveals 113 studies (including Master theses) which refer to Ojakangas' dissertation. However, most of them do not approach the dissertation's results from a historical perspective, and seem to ignore the particular scope of his research. The results based on more normative sources have not taken into account the material level or the perspective of gradual change; and nor has this been explicated by Ojakangas either. This, however, is a topic worthy of a more detailed review article which will be addressed in due time. 
was based mainly on the teacher's gaze, and that in the context of twentieth-century schools, the gaze of the teacher can be understood as a disciplinary measure or form of punishment, albeit a gentle one. ${ }^{21}$

Despite the merits of previous research, we argue that automatically subscribing to a more general perspective that wider frames of reference entail may explain why certain sources have been overlooked in favour of seemingly more comprehensive sources such as teaching manuals, pedagogical writings and guidebooks. ${ }^{22}$ These are certainly important for understanding the intellectual and regulatory history of discipline in education, but just like our work here, they convey only a part of the complex issue. There is thus the need for a additional research in order to establish a more plurivocal approach to the study of punishment, disciplinary practices, and the norms and regulations governing them. It cannot be assumed that ideals were implemented as fully and swiftly as previously thought, ${ }^{23}$ as the cultural preconditions necessary for norms and regulations to change take time ${ }^{24}$ - teachers may have, for instance, learned a different set of values in their own training.

In this article we use the term "corporal punishment" as an umbrella concept to describe the kinds of physical violence ${ }^{25}$ used in schools for the purposes of discipline. But as indicated earlier, "violence" is a complex concept to define, and it is easy to be anachronistic. For instance, spanking was forbidden as a form of violent punishment, though some contemporaries saw it as a legitimate means of chastisement. ${ }^{26}$ But equally, the incarceration of misbehaving pupils, which would nowadays be seen as violence (and was also discouraged by educationalists at the time), was actually sanctioned by the School Order Act of 1872 - putting it in a similar grey-area category to corporal punishment. This highlights the importance of historical research to check for anachronism. Most importantly, it highlights how complex the regulations and ideas concerning punishment were, when examined at the practical and material level.

From a normative perspective, one could say that forms of discipline which exceed legal limits constitute violence. But corporal punishment in the past is not as straightforward. What was either forbidden or frowned upon normatively and in the

21 Landahl, (2013), 804-6, 812-16.

22 See, for instance, Landahl (2013); Launonen (2000); Ojakangas (1998). One of the few exceptions is Germund Larsson, Förbrytelser och förvisningar: Bestraffningssystemet $i$ de svenska läroverken 1905-1961 (Uppsala: Uppsala University, 2018).

23 Previous works have seldom explained their limitations, especially with regard to external source criticism, with the result that, for the past 30 years, research has been building on it without giving much consideration to evidence from supplementary sources; suggesting there is a need, as Cowen and Rappleye have noted, for more critical long-term research in the history of education. The use of other sources throw these complex issues into a new light. For instance, recent historical research on the mistreatment of children in foster care has unearthed a lingering culture of physical and mental abuse. Cf. Hytönen et. al. Lastensuojelun sijaishuollon epäkohdat ja lasten kaltoinkohtelu 1937-1983 (Sosiaali- ja terveysministeriön raportteja ja muistioita 2016:22; 2016).

24 For more on slow changes in mentalities see, for instance, Matti Peltonen, Matala katse: Kirjoituksia mentaliteettien historiasta (Tampere: Hanki ja jää, 1992).

25 As a purely descriptive term.

26 Corporal punishment was a common practice in Finnish homes, and it was not until 1983 that it was officially abolished: see, for example, Jaana Kemppainen, Kotikasvatus kolmessa sukupolvessa (Jyväskylä: University of Jyväskylä, 2001). 
public sphere was legally allowed in the private, where it was in some ways "business as usual." 27

But there have recently been new interdisciplinary approaches to the study of violence. For instance, theoretically somewhat understudied ${ }^{28}$ topic of interpersonal violence has been given a more detailed account recently with emphasis given to spatiotemporal approaches as well as gendered forms and practices of violence. ${ }^{29}$ Likewise, the matter of ethical questions in the study of delicate matters such as violence related to people in vulnerable positions has garnered renewed and important interest also in history. ${ }^{30}$ These kind of recent contributions have contributed to the possibilities of adding also to the vast corpus tackling the theme of discipline ${ }^{31}$ and punishments in school, corporal in particular. ${ }^{32}$ Despite the vast use of these kinds of euphemisms, the disciplinary element of punishments in the history of education is also about the study of violence.

\section{Sources}

A vast array of punishment records from Finnish secondary schools ${ }^{33}$ have stood the test of time. These "punishment books" 34 are in many ways quite unique in the way they complement existing source material. Although they provide only a limited national basis for our analysis and thus are not easily generalisable, they do, however, provide a valid test case for reevaluating the limitations of normative sources used previously in the literature, and add a perspective to existing knowledge not previ-

27 Jari Eilola and Heli Valtonen, "Perheen sääntely modernisoituvassa Suomessa," in Kansallisten instituutioiden muotoutuminen - Suomalainen historiakuva Oma Maa - kirjasarjassa 1900-1960, ed. Petri Karonen and Antti Räihä, (Suomalaisen Kirjallisuuden Seura 2014), 83-89, 96-106.

28 Marita Husso, Helena Hirvonen and Marianne Notko, "From Rejection to Understanding: Towards a Synthetic Approach to Interpersonal Violence," in Interpersonal Violence: Differences and Connections, ed. Marita Husso, Tuija Virkki, Marianne Notko, Helena Hirvonen, and Jari Eilola (London/ New York: Routledge, 2017).

29 Marita Husso et al., eds., Interpersonal Violence: Differences and Connections (London/New York: Routledge, 2017).

30 Satu Lidman, Anu Koskivirta and Jari Eilola, eds., Historian tutkimuksen etiikka (Helsinki: Gaudeamus, 2017).

31 The distinction between punishment and discipline are many but must be addressed elsewhere: see, for example, Marcelo Caruso, "Order Through the Gaze: A Comparative Perspective of the Construction of Visibility in Monitorial Schooling (German States - Spain, approx. 1815-1848)," Encounters on Education 9, no. 2 (2008); Esbjörn Larsson, En lycklig Mechanism: Olika aspekter av växelundervisningen som en del av 1800-talets utbildningsrevolution (Uppsala: Opuscula Historica Upsaliensia, 2014), 183-259.

32 In the US context, regarding issues of race in disciplinary practices, see, for example, Pedro A. Noguera, "Schools, Prisons, and Social Implications of Punishment: Rethinking Disciplinary Practices," Theory Into Practice 42, no. 4 (2003).

33 In early twentieth-century Finland, secondary school (oppikoulu) denoted a different type of school that prepared pupils for university. Secondary school is thus to be understood as a general concept referring to mixed and single sex schools, with lower and upper levels and particular curriculums. Up until the 1960s they were considered to have played an important role in educating those that would become the elite. Mervi Kaarninen, "Oppikoulu yhteiskunnan rakentajana," in Valistus ja koulunpenkki: Kasvatus ja koulutus Suomessa 1860-luvulta 1960-luvulle, ed. Anja Heikkinen and Pirkko Leino-Kaukiainen (Helsinki: Suomalaisen Kirjallisuuden Seura, 2011); Kiuasmaa (1982), 19-31, 46-54; Strömberg (2011).

34 Rangaistuskirja or rangaistuspäiväkirja in Finnish. 
ously taken. ${ }^{35}$ Similar sources can be found in other countries-for instance, punishment records were kept in some British schools during the twentieth century-but they have not been systematically utilised. ${ }^{36}$ A review of the National Archives of Finland reveals that punishment records were kept in at least 106 secondary schools across the country in the early twentieth century. ${ }^{37}$

In this article we analyse punishment records kept by teachers in three different secondary schools: one for girls (in Tampere), one for boys (the Lyceum in Jyväskylä), and one mixed (the Coeducational in Kuopio). The schools were selected as they represent all three forms of secondary school existing in Finland at the time. Moreover, being in different municipalities, they provide a wider perspective on the status of school discipline in the whole of Finland. As each school was an educational nexus for their region, they would draw pupils from surrounding rural communities. In addition, all three schools' punishment records were intact.

Each of these schools was state-supervised and therefore regularly inspected..$^{38}$ The importance of keeping punishment records is confirmed by the sheer number of punishments in general. That there are so many instances rules out the chance of them being anomalies, but just why these were recorded so meticulously remains unclear. That they were recorded at all reveals that, for one reason or another, records of the punishments administered (even those frowned upon, as we shall see) were considered important. Also the inspection provides some credibility for these sources with regard to external criticism. As an exploratory account, and supplemented with other sources, this provides enough source material for testing the source-type so that additional findings can build a more detailed account on top of ours later on.

The records mainly list pupil offences and the punishments issued. They contain the name and class of said pupil, and the date of the reported offence. Most of them

35 We have conducted an extensive literature review of previous research (across databases such as Finna, EBSCO, JSTOR, LIBRIS, and with the exceptions of Ydesen (see below) and Puranen, have not found any that explicitly use punishment records to their full extent. Such research no doubt exists, but the present authors have not been able to find any such work in Swedish, Finnish, or English. A less extensive search was also conducted in German, and revealed no specific instances. Consulting various history of education specialists in conferences has also indicated that this kind of research using such source material is novel. It is hoped this is sufficient background research for a case study in the purely Finnish context, and the authors would welcome any findings, contrary or otherwise, from elsewhere.

36 Christian Ydesen consults the punishment books of two English schools to some extent: see Christian Ydesen, "Crafting the English Welfare State-Interventions by Birmingham Local Education Authorities," British Educational Research Journal 42, no. 4 (2016), 624-625.

37 Though having searched several different databases, we have found relatively little studies that use these kinds of record as a source. The number of secondary schools increased rapidly in the early twentieth century - from 96 in 1900 to 232 (of which approximately 106 had punishment records) in 1930: Puranen, 2015. See also Kaarninen (2011), 412.

38 Inspectors of the National Board of Education visited secondary schools every few years to check that the school was following the national curriculum and that the teaching was suitable from all angles: see for instance Jukka Rantala, "Oppikoulunopettajat" in Valistus ja koulunpenkki: Kasvatus ja koulutus Suomessa 1860-luvulta 1960-luvulle, ed. Anja Heikkinen and Pirkko Leino-Kaukiainen (Helsinki: Suomalaisen Kirjallisuuden Seura, 2011), 309-310. Inspectors visited all three schools examined in this article and examined the punishment records, as discipline was seen to be an important part of a child's education, see for example School Inspection Reports (Tarkastuspöytäkirjat), November 13 1906, Cb:1, Kuopion yhteiskoulun arkisto (KYA), Finnish National Archives (FNA); School Inspection Reports, December 6 1907, Cb:1, Tampereen tyttölyseon arkisto (TTA), FNA. 
also contain signatures by the teachers and the dates when the punishments were carried out. This also confirms to some extent that the punishments issued were not just of a descriptive nature, and did actually take place. The records were not created simply for the sake of school inspections, as it seems they were also kept for internal accounting and administrative purposes. For instance, detention required bookkeeping to check it had been carried out.

This kind of official source created for certain purposes should be considered with due caution. ${ }^{39}$ Due to regular supervision by inspectors, one can safely assume that these records would most likely only contain the kind of information permitted by school legislation, so any illicit punishment method or anything contradicting them, such as corporal punishment, was less likely to be recorded in the punishment book, as this could harm the school or the teachers. Nevertheless, we have found plenty of punishments, including corporal, recorded there. ${ }^{40}$ Bias in what was recorded could also work the other way-in that only punishments of a certain severity were recorded. For instance, school memoirs and histories show that punishments given in immediate reaction to something, such as clip over the ear would have been given ad hoc, ${ }^{41}$ and not written down. Nevertheless, the administrative nature of these documents ensures that in spite of these caveats, these sources could be considered rather reliable. For as the teachers kept them carefully, it is likely that there are few irrelevant notes in them and should at least enable a partial reconstruction of the past. In addition, the external inspection of the punishment records served at least to some extent to ensure that potential anomalies or oddities would have been noticed. Then again, the position of the teachers in their respective profession, which also added the responsibility related to practicing a respected profession, would have made challenging the records and record keeping practices very difficult. In other words, as is with all source material, one cannot claim that the records should not be considered with both external and internal source criticism. In future the possibility of anomalies can be tackled to some extent with the use of wider source-base, which will help in detecting potential oddities.

To broaden our understanding of the punishment practices implemented, we also examine school memoirs and histories written by former pupils of the schools, as well as the minutes of staff meetings and inspection reports. We analyse them, in addition to punishment records to see whether the normative and legislative changes ${ }^{42}$ were actually carried out. These records combine to provide a means through which the systemic and endemic changes to school discipline can be properly scrutinised at the material level, enabling our case-driven and exploratory research to reassess and thereby contribute to previous research on the topic.

39 Kaisa Vehkalahti, Daughters of Penitence: Vuorela State Reform School and the Construction of Reformatory Identity, 1893-1923 (Turku: University of Turku, 2008), 20. Vehkalahti refers to official sources in general, and argues that they should be approached in a historical method and using the principles of source criticism.

40 See tables 1 and 2 below.

41 Paavo Alkio, “Koulumuistoja Vaasan lyseosta," in Vaasan lyseo 1880-1980, ed. Alpo K. Rapila, (Vaasa: Vaasan lyseon entiset oppilaat, 1980); Jaakko Haavio, Mennyttä aikaa muistelen (Helsinki: Kirjapaja, 1972); Ilmari Turja, "Sotavuosien lyseo," in Vaasan suomalainen lyseo 1880-1930, ed. Artturi Järviluoma, (Vaasa: Vaasan kirjapaino, 1930).

42 For this we mainly use the original legislative material, and to some extent the considerable previous research on the ideals and norms of contemporary educationalists. 


\section{Methodology}

As this is exploratory research, our methodology is relatively straightforward. The sources have been chosen taking into account contemporary views on school discipline (to avoid anachronism), and that this was the Finnish education system's formative period; and with the aim of collecting all instances of punishment that could possibly relate to the research question. Based on those instances found, the punishments (and the related offences) have been categorised, and are presented in table 1 (and 2). These punishment categories are based on distinctions made in the School Order Act of $1872 .{ }^{43}$

In our search for possible instances of corporal punishment, we have applied what could be described as grounded theory, which is often used in exploratory research to try and address the limitations of flexibility and/or resilience imposed on novel ideas by a stricter theoretical framework. ${ }^{44}$ In other words, we have gathered together all possible findings and gone through them to find where clustering occurs, and then used the clusters to determine each category. It should also be noted that the findings were analysed for their characteristic features in a qualitative manner, in the full awareness of external and internal source criticism. We then drew our conclusions after comparing the subsequent results to school legislation and the existing research (based on more normative sources).

\section{2: Changing regulation}

Up until the School Order Act of 1872, teachers had been able to use what was referred to as a "ferule" ${ }^{45}$ to punish misbehaving pupils, ${ }^{46}$ and although corporal punishment was now officially forbidden by the new legislation, as mentioned earlier, punishments were certainly still administered and actually, to some extent, even sanctioned by the legislation in 1872 . Indeed, there were nine different forms of punishment that continued to be used in boys' and coeducational schools and two different kinds in girls' schools. The punishment methods used in boys' schools, in increasing measures of severity, were: (i) warning and reprimand in front of classmates; (ii) separation from friends; (iii) drop of rank in classroom; ${ }^{47}$ (iv) detention; (v) strict warning; (vi) incarceration; (vii) advice to leave the school (consilium abeundi); (viii) suspension; and in the worst case, (ix) expulsion..$^{48}$ Classroom teachers could independently administer punishments up to and including category (v), but more severe punishments above that level needed the joint approval of the headteacher, and for expulsions, the entire teaching staff was consulted. ${ }^{49}$ Warnings and expulsions were the only two punishments legally allowed in girls' schools. ${ }^{50}$

43 KMAKS, August 8, 1872, \$39.

44 Barnet G. Glaser and Anselm L. Strauss, Discovery of Grounded Theory: Strategies for Qualitative Research (Routledge, 1999); Kathy Charmaz, "Grounded Theory as an Emergent Method," in Handbook of Emergent Methods, ed. Sharlene Nagy Hesse-Biber and Patricia Leavy, (New York: Guilford Press 2008),155-72. In this case our coding of the source material is conducted only at the first level due to a limited amount of source data.

45 A ferule was a flat ruler with a widened end used to administer corporal punishment.

46 HKMNG, November 6 1843, § 79-99.

47 This meant de facto changing the seating order in the class.

48 Translation by the authors: KMAKS, August 8, 1872, 39\$, 40\$.

49 KMAKS, August 8, 1872, 40\$. See also Kiuasmaa 1982, 122-29.

50 KMAKS, August 8, 1872, 40§, 47\$. 
It is worth noting that the Act of 1872 , replaced corporal punishment methods with those of isolation and surveillance. Detention was a punishment based mainly on surveillance, and was the act's main focus. As noted by earlier studies, it replaced corporal punishment - at least in legislative terms ${ }^{51}$ — as educationalists began to emphasise softer forms of discipline. They thought surveillance methods such as these helped misbehaving pupils focus on self-discipline, whereas corporal punishment (according to numerous normative sources) did not have any such pedagogical benefits $^{52}$ — based as it was on physical power and fear. This meant that, by the early twentieth century, discipline in Finnish secondary schools, was officially based on surveillance and isolation methods of punishment, although corporal punishment was nonetheless tolerated. According to Foucault, this shift towards the use of softer punishment methods is explained, not so much by humanitarian demands for reform, as by the institutional will to reform systems of judgement and punishment so that they can be controlled in a more effective manner. ${ }^{53}$

\section{Punishment galore...}

Detention was by far the most commonly recorded punishment method in both the Coeducational school in Kuopio and the Lyceum in Jyväskylä, as we can see from table 1 below. For 92.7 per cent of all the offences (1481 out of 1600) recorded in the punishment book in Jyväskylä for the period 1896-1905, the punishment was detention; while in Kuopio it was even higher at 98.4 per cent (1922 cases out of 1954). None of the other punishment methods permitted were used anywhere near as often.

Table 1. Punishments in two schools

\begin{tabular}{|l|cc|ccc|}
\hline Punishment & \multicolumn{3}{|c|}{ Coeducational school } \\
\hline Detention & \multicolumn{2}{|c|}{ Boys'school } & Boys & Girls \\
Incarceration & 1487 & $92.9 \%$ & 1752 & 170 & $98.4 \%$ \\
Warning & 32 & $2.0 \%$ & 17 & 0 & $0.9 \%$ \\
Strict warning & 34 & $2.1 \%$ & 5 & 0 & $0.3 \%$ \\
Suspension & 4 & $0.3 \%$ & 1 & 2 & $0.2 \%$ \\
Advice to leave (consilium abeundi) & 2 & $0.1 \%$ & 3 & 1 & $0.2 \%$ \\
Separation from friends & 5 & $0.1 \%$ & 1 & 0 & $0.0 \%$ \\
Other & 18 & $1.1 \%$ & 1 & 0 & $0.0 \%$ \\
No punishment recorded & 17 & $1.1 \%$ & 1 & 0 & $0.0 \%$ \\
\hline Total & 1600 & $100.0 \%$ & 1781 & 173 & $100.0 \%$ \\
\hline
\end{tabular}

As noted in the previous chapter, detention was a punishment that was not necessarily perceived by contemporaries as harsh as other permitted forms, and it best enabled the surveillance recommended by educationalists, too. So it seems that, on

51 KMAKS, August 8, 1872, 40\$.

52 See for instance Ojakangas (1998); Launonen (2000).

53 Foucault (1977). 
a practical level too, surveillance was indeed central to punishment in schools as claimed by previous research.

However, it is the sheer quantity of punishments that we see in table 1 which contradicts the findings of previous research. Mika Ojakangas, for instance, states that educationalists generally held that punishments were supposed to be an exception to the everyday life of a school; and that teachers were thought to have failed in their task if they had to rely methods of punishment other than the disciplinary gaze. ${ }^{54}$ Yet, in table 1 we can see that a total of 1600 punishments were administered at the boys' school, and nearly 2000 at the coeducational. This means an average of approximately 200 recorded punishments per year which makes it quite difficult to believe that stronger punishments were a rare occurrence or that school discipline relied on the punitive gaze alone. This reality becomes even more stark when we consider that the schools in question had approximately 200 pupils per year for the period in question (1895-1905), that in the Lyceum a yearly average of 178 punishments were issued, and that in the Coeducational the average was 217 . This means that-even if each pupil was only punished once a year-almost all of the pupils would have been punished at least once a year. ${ }^{55}$

Perhaps each pupil getting punished once a year doesn't sound like that much, but the records also show that punishments were not shared equally and that there were certain groups of pupils that got punished more than others-for instance, girls were seldom punished-which means that for others punishment was more common. We do not go further into what precisely was considered "normal" behaviour in this article, but the threshold for issuing punishments must have remained low in spite of the fact that punishments were supposed to be avoided at all cost.

In 1926, even the school inspector who visited the Coeducational School in Kuopio, noted that detention was used too often. He observed that, altogether, an average of 300 detentions had been recorded yearly. ${ }^{56}$ If we consider that 1926 was several decades since educationalists had started advocating less punishment, then we can suppose their recommendations would have been widely adopted by this point and that the threshold for issuing punishments would have thus been higher. But if that was the case, then roughly 200 punishments per year still seems quite a lot; meanwhile in the year 1905-1906, this figure was 280. ${ }^{57}$ Another aspect of detention was that by isolating the pupils for a certain amount of time it taxed their time, not to mention having the potential to shame them.

The high number of punishments overall also indicates that the Foucauldian panopticon and emphasis on the significance of surveillance in schools cannot completely explain the punishment practices observable at the everyday level that were still going on in early twentieth-century schools. Based on our findings in all three schools we investigated, surveillance and the punitive gaze were certainly not considered sufficient, as other methods of punishment besides detention were employed relatively often, such as school jail (karsseri) for the more troublesome pupils, which both isolated them and kept them under surveillance. This was the second

54 Ojakangas (1998), 55-58. See also Landahl (2013); Launonen (2000), 135-48.

55 There were around 200 pupils in Jyväskyläs Lyceum, while in Kuopio's Coeducational there were approximately 250: Suomen virallinen tilasto, IX, Oppikoulut, 1895-1905.

56 Seppo Hannula, Kuopion yhteiskoulun vaiheet 1892-1967 (Kuopio, 1967).

57 JoMA, KYA, Ad:1 and Ad:2. 
most common punishment in both the Jyväskylä and Kuopio schools, and mainly reserved for pupils over the age of 14 . Pupils that faced this punishment were confined to a small cell for a maximum period of twelve hours per day. This was to be served over a period of three days, meaning altogether 36 hours of incarceration..$^{58}$ "School jail" was nevertheless seen as more severe than detention, ${ }^{59}$ and shows that punishment was not becoming quite such a thing of the past as educationalists at the time would have liked, and previous literature based on normative sources suggest. Finnish educationalists were certainly not specifically recommending this form of punishment as total isolation was seen as harmful. ${ }^{60}$ Nevertheless our findings reveal that school jail, banned in Swedish secondary schools already in the early nineteenth century, ${ }^{61}$ was a form of school punishment still practised in Finland. Naturally, one could expect not all punishments to be recorded if they ran contrary to the norms of the day, as this might have reflected badly on the staff and school, and yet we have found plenty of cases where punishments were in fact meticulously recorded, including instances of corporal punishment.

The girls' school in Tampere is omitted from table 1 as the punishment practices there differed significantly from the other two schools. This was mainly due to legislation, and thus it is not reasonable to compare the disciplinary practices there to the other two schools in the same table. Nevertheless, between 1893 and 1913, nine punishments were noted in the school's punishment record, adding to the general impression that punishments were still being carried out, at least to some extent. In almost all of the cases, the alleged offender was either suspended or expelled. ${ }^{62}$

This leads us to the reasonable conclusion that school punishment practices were gendered. We can see, for instance, from table 1 that girls in the mixed school in Kuopio were punished markedly fewer times than the boys, especially when one also considers that 58 per cent of the pupils were girls between 1895 and $1905 .{ }^{63}$ Furthermore, girls at this school were seldom punished with harsher methods, even though legislation regarding coeducational schools would have allowed this. For instance, none of the punished girls in Kuopio were given time in the school jail though it was legally possible, whereas school jails were legally proscribed in all-girl schools. This leads us to believe that perhaps the legislation regarding all girls' schools was also informally implemented in coeducational schools, the first of which were founded several years after the legislation regarding punishments used in them was passed. ${ }^{64}$ The gendered differences between punishment practices become even more evident when we bear in mind that the only permissible punishments in all-girl secondary schools were warning and expulsion. ${ }^{65}$

58 KMAKS, August 8, 1872, \$ 40.

59 Kiuasmaa (1982), 128; Ojakangas (1998), 63. The fact that pupils were incarcerated for the same kinds of offence that they would have received corporal punishment for suggests that this form of punishment was also a potential form of violence.

60 Ojakangas (1998), 63.

61 Norlin (2016).

62 Rangaistuskirjat, Ae:1, TTA, FNA.

63 The proportion of females grew during the whole period being, for instance, in school year of 19041905 already 67 percent; see Suomen virallinen tilasto, IX, Oppikoulut, 1895-1905.

64 See for example Kaarninen (2011).

65 KMAKS, August 8, 1872, 47§. Certain peculiarities can be found in the text defining the use of 
But it is the sheer overall number of punishments that continued to be administered which raises the possibility that corporal punishment might also still be being practised. If the educationalists did not take into account the practice of punishments in general, then perhaps they also overlooked the types of punishment actually being carried out. ${ }^{66}$

\section{...but with little "violence"?}

As we saw from table 1, plenty of punishments did get recorded in spite of the apparent paradigm shift that educationalists maintained had occurred; and as this was evidently going on unbeknownst to them at the practical level, it also gave us reason to suspect that we should look out for any instances of corporal punishment recorded. So it was, while gathering data, that we found four directly applicable cases. These are presented in table 2 below.

Table 2. Cases of corporal punishement

\begin{tabular}{|c|c|c|c|c|c|}
\hline Case & $\begin{array}{l}\text { Year group/ } \\
\text { grade of } \\
\text { offender }\end{array}$ & Offence & Punishment & $\begin{array}{l}\text { Offender's } \\
\text { gender }\end{array}$ & Source \\
\hline 1. & $1 \mathrm{st}$ & $\begin{array}{l}\text { "Illicit use of his } \\
\text { father's name in } \\
\text { front of the head- } \\
\text { teacher" }\end{array}$ & $\begin{array}{l}\text { "Corporal } \\
\text { punishment by } \\
\text { father" }\end{array}$ & Male & $\begin{array}{l}\text { Punishment } \\
\text { record of the } \\
\text { Coeducational } \\
\text { school of Kuopio }\end{array}$ \\
\hline 2. & $1 \mathrm{st}$ & $\begin{array}{l}\text { "Forgery" } \\
\text { (Additional note: } \\
\text { "Forged the sig- } \\
\text { nature of his gu- } \\
\text { ardian, the town's } \\
\text { public prosecutor } \\
\text { XX, in his diary") }\end{array}$ & $\begin{array}{l}\text { "Spanking by } \\
\text { father and a } \\
\text { warning in } \\
\text { front of his } \\
\text { classmates" }\end{array}$ & Male & $\begin{array}{l}\text { Punishment } \\
\text { record of the Ly- } \\
\text { ceum of Jyväskylä }\end{array}$ \\
\hline 3. & $\begin{array}{l}\text { Preparatory } \\
\text { grade }\end{array}$ & $\begin{array}{l}\text { Did not show his } \\
\text { diary to home and } \\
\text { forged his father's } \\
\text { signature }\end{array}$ & $\begin{array}{l}\text { Spanking by } \\
\text { father }\end{array}$ & Male & $\begin{array}{l}\text { Minutes of staff } \\
\text { meetings, the } \\
\text { Coeducational } \\
\text { school of Kuopio }\end{array}$ \\
\hline 4. & $1 \mathrm{st}$ & $\begin{array}{l}\text { "Fighting and act } \\
\text { of violence" }\end{array}$ & $\begin{array}{l}\text { "Detention } \\
\text { and corporal } \\
\text { punishment at } \\
\text { home" }\end{array}$ & Male & $\begin{array}{l}\text { Punishment } \\
\text { record of the Ly- } \\
\text { ceum of Jyväskylä }\end{array}$ \\
\hline
\end{tabular}

Based on just the findings presented in this table alone, it is clear that sending pupils home for a beating happened only rarely in the schools we examined, but it is worth considering the kinds of situation in which they did resort to this practice. If we go back to the Act of 1843, it did not directly specify which misdemeanours merited

punishment in girls' schools. "Lecherous" (irstas) and "malicious" (pahantahtoinen) girls were supposed to be expelled, and warnings were to be issued as gently as possible.

66 See also Puranen (2015), and Puranen, doctoral dissertation (forthcoming in 2019). 
"milder" forms of corporal punishment nor which the "stricter;" but carelessness, disobedience and something described as "ill-mannered behaviour," are all mentioned as meriting punishment in general. ${ }^{67}$ It is therefore worthwhile investigating, in everyday school practice, the particular instances when corporal punishment was called for, to consider whether the instances were indeed rare oddities, or rather the tip of an iceberg representing a punishment culture that was lingering on well after legislation had supposed to have changed all that. The following is an account of the specific empirical instances of corporal punishment we found.

The first incident found was recorded in the punishment books of the Coeducational school of Kuopio on 31 March, 1906. According to the sources, a first-year pupil was sent home to be spanked for the "illicit use of his father's name in front of the headteacher." ${ }^{18}$ What this means exactly is not clear as there is not much further information available, but "father" was written without a capital letter which would indicate the paternal rather than divine kind (unless the lack of capitalisation was a typographical error).$^{69}$ As it happens, it was common at the time to refer to God as the "Father," and would correspond to the significant role the Church previously had in organising education in Finland.

But perhaps the most likely explanation is that the child uttered a rather common profanity "jumalauta" (which literally means "God help me"), which would have counted as thoroughly unsuitable profanity and swearing in a school context, and significantly, would not have required a capital letter when referred to. Also, such an offence is more likely to have merited a spanking than the pupil cursing his own father without any further explanation in the punishment records. After all, education had been in the hands of the Church for a long time previously, and this could have been another case of certain cultural practices lingering on-in this case with regard to previously strict religious regulations.

The second case occurred in 1899 at the boys' Lyceum in Jyväskylä, where another first-year was punished with "spanking by his father and a warning in front of his classmates" for forging the name of his guardian in his home-school diary. ${ }^{70}$ In the end, this particular pupil left the school soon after this to be closer to his parents in Ostrobothnia. ${ }^{71}$ In general, pupils were punished with detention mainly for "boisterous behaviour," ${ }^{2}$ such as running through the school or speaking without permission. If the punishment for minor offences such as these was detention, then it might well have been that there were no permitted disciplinary procedures left for the school beyond expelling the student for far more serious crimes, and perhaps this case of forgery was serious. But was it more serious than other cases of forgery or deceit in the school records? The punishment certainly seems stricter, when one thinks that other cases of deceit would instead earn a spell in detention or school

67 HKMNG, November 6 1843, $\$ 86$.

68 Rangaistuspäiväkirjat, March 31 1906, Ad:2, KYA, FNA.

69 Rangaistuspäiväkirjat, March 31 1906, Ad:2, KYA, FNA.

70 Rangaistuskirjat, March 17 1899, II Ae:1, Jyväskylän lyseon arkisto (JYLA), FNA. A diary in this context most likely meant a supervisory device of some sort, in which the pupils' behaviour or grades, assignments or such were recorded. There is, apparently no surviving examples of the said "diaries" which might enlighten the instance more.

71 Eero Mikkola et al., eds., Jyväskylän lyseo 1858-1983 (Jyväskylä: JYLY, 1983), 132.

72 "Vilkkaus" in Finnish. 
jail. ${ }^{73}$ We have found only one case of (multiple) forgeries by a pupil. In that case, a more serious offence by far, the pupil was expelled, ${ }^{74}$ so just why this case of a single forgery merited corporal punishment is somewhat of a mystery.

Perhaps it was a case that corporal punishment was much easier to hide than an expulsion, which meant de facto that a school had failed in its main duty to turn out well-behaved and law-abiding individuals. ${ }^{75}$ Expulsion was thus perhaps the last resort, as it brought shame on the school, the teachers, and high-ranking members of the local community. In light of this, recourse to "old school" methods such as spanking might have seemed the most viable option to staff. This might also explain the unusually rich details in the punishment record entry, as the background to offences are seldom described-it was usually noted in the punishment record as simply "deceit."

In this case, even the name of the guardian (whose signature was forged) was recorded. The guardian held a respected position in the local community, as Jyväskylä's public prosecutor ${ }^{76}$ and might explain why the forged signature of such a high-ranking official was considered a particularly serious offence, especially when the prosecutor was a guardian and not the pupil's actual father. The father himself also had a relatively high position and reputation to protect as a bailiff too. ${ }^{77}$ Protecting the school's reputation and the rank of both these men might explain some of the oddities in the record and why the pupil earned a beating from his father rather than getting expelled. Compared to expulsion, corporal punishment was less public, delivered as it was within the walls of a home or school, whereas expulsion was a loselose situation for both pupil and school. Another observation that can be made is that, generally speaking, the lower the socioeconomic background of the pupil the harsher the punishment. ${ }^{78}$ Perhaps the meticulous record-keeping here was simply an attempt to show that no favouritism was shown to the bailiff's son, and that corporal punishment was the optimal solution for all involved-harsh enough, yet leaving reputations intact.

The third case consists of an instance mentioned in the Kuopio mixed school's staff meeting minutes. A pupil had not shown his home-school diary to parents, and was suspected of forging his father's signature in the diary. The father was formally asked by the school to physically discipline his son, but it seems that this was only after the father himself had suggested it. In addition to receiving a spanking the pupil also lost two points in his classroom behaviour ranking. ${ }^{79}$ The case here, that the father suggested administering corporal punishment at home, which would have fallen within the cultural and legitimate practice of chastisement, lends credence

73 Rangaistuspäiväkirjat, Ad:1 and Ad:2, KYA, FNA; February 41902 and March 18 1904, II Ae:1, JYLA, FNA.

74 Staff Meeting Minutes (Opettajankokousten pöytäkirjat), February 4 1899, Ca:1, KYA, FNA.

75 Norlin (2016), 275-276; Puranen (2015).

76 Kaupunginviskaali: Veli-Matti Autio, Ylioppilasmatrikkeli 1853-1899, (Helsinki: Helsingin yliopisto, 2010), https://ylioppilasmatrikkeli.helsinki.fi/1853-1899/henkilo.php?id=20386 (accessed December 10, 2017); Mikkola et al., 96.

77 Autio, https://ylioppilasmatrikkeli.helsinki.fi/1853-1899/henkilo.php?id=18545; Päivö Oksala et al., eds., Jyväskylän Lyseon satavuotishistoria 1858-1958 ja juhlajulkaisu (Jyväskylä: Oy Sisä-Suomen kirjapaino, 1958), 240.

78 Puranen (2015), 75-97.

79 Staff Meeting Minutes, February 28 1899, Ca:1, KYA, FNA. 
to the idea that harsher punishments such as these may have been "outsourced" by schools to avoid them getting into trouble.

The fourth record of corporal punishment was from the Lyceum. Again, it was a first-year that was given corporal punishment; but this time it was for "fighting and an act of violence." ${ }^{80}$ In this case too, corporal punishment was not considered enough as the pupil also received one hour's worth of detention. It is interesting that, as in the 1899 case above, punishments were received both in school and (outsourced) at home. Unfortunately, there are fewer details recorded for this fourth case, but there is another punishment record from the same day, in which another first-year pupil was punished for "fighting," but received only an hour's detention. ${ }^{81}$ Although it is not explicitly mentioned, it is likely that these pupils were punished for fighting each other as they were in the same year and the entries are next to each other in the punishment records. Pupils were rarely accused of fighting and, when they were, the punishment was generally detention. This leads us to think that the "act of violence" that merited our fourth case of corporal punishment must have been something more serious, and for this violent offence, an equally "violent" (in this case corporal) punishment was required. Perhaps this offender also started the fight, but there is no further information to be sure of this.

Overall, we found very few directly applicable cases of corporal punishment. All of the instances we found were outsourced privately, using the practice of chastisement that was still allowed. Moreover, it was only issued for offences deemed serious enough, making corporal punishment a rarity. Nevertheless, by outsourcing it, corporal punishment was being condoned by schools, even if surveillance and isolation were the primary methods used within schools for punishment-as we can see even from our micro-sample in table 1.

It is interesting that the threat of corporal punishment therefore persisted after the Act of 1872 and that the practice was certainly not abandoned altogether. This is contrary to the more general notions in previous research on discipline and punishment, which have not explicitly addressed the possibility that these "old school" practices may have still been going on. It seems corporal punishment was used in instances where "asking" 82 pupils to leave the school would have caused a lot more trouble for everyone involved than simply sending pupils home for a proper spanking. ${ }^{83}$ Indeed it is worth noting that teachers also even had the right to spank pupils, if given the assent.

However, if the parents or guardian of the pupil immediately correct the pupil with a suitable method of disciplinary action, or the headmaster (with their assent); and should the pupil show signs of improvement after this, then the expulsion, after a definite period of time, can be reversed. ${ }^{84}$

80 Rangaistuskirjat, October 21 1905, II Ae:1, JYLA, FNA.

81 Rangaistuskirjat, October 21 1905, II Ae:1, JYLA, FNA.

82 "Advice to leave" (consilium abeundi) in effect meant expulsion: see KMAKS, August 8, 1872, §39, $\$ 40$ and Kiuasmaa (1982).

83 KMAKS, August 8, 1872, \$40; Kiuasmaa (1982), 128.

84 "Mutta kuitenkin, jos vanhemmat tahi holhumies soveljaalla kurituksella heti oikaisevat oppilasta, taikka rehtori, heidän suostumuksellansa, semmoista kuritusta antaa, ja jos sen kautta nähtävä parannus on tullut, mahtakoon määrätyn ajan loputtua säädetty erorangaistus jäädä sikseen." KMAKS, August 8, 1872, \$40 
In previous research this practice has not been considered in such detail. Outsourcing the judgement like this was clearly one way round the legislation. The important point is, that it was still the school that was was issuing the punishment though, even if it was administered at home. The school was still using corporal punishment as an option, and resorting to violence even if this was on rare occasions (judging from our sample). As there is no way around the fact that outsourcing corporal punishment to the child's home reflected back on the school, it is worth considering whether a wider array of sources might reveal more such instances, especially when we see that punishments were still being given and this is ignored by previous research which relies on normative sources.

It is also worth bearing in mind, that an imperial statute actually banned the use of corporal punishment in educational facilities (in this case primary schools in particular) was issued in 1914 stating that

by changing and supplementing the regulations regarding the matter of corporal punishment in educational facilities and schools upheld and supported by the state, [the statute] forbids the use of corporal punishment. ${ }^{85}$

The outsourcing of corporal punishment by schools was therefore against the spirit, if not the letter, of the law-even if the more violent aspects of "chastisement" in homes was still legitimate. Kiuasmaa has also made this interpretation, although he also adds that "the statute did not de facto prevent the practice of chastisement administered at home, on behalf of other, very harsh, school issued, punishments." 86 This supports our argument that a culture of corporal punishment remained in education longer than has previously been thought. As late as 1920, punishment records reveal similar kinds of incidents, where pupils are being sent home to receive corporal punishment 'authorised' by the school. ${ }^{87}$ In fact, the legislation allowed the practice indirectly to continue until as late as $1965 .{ }^{88}$ Only the statute of 1972 removed this loophole altogether. ${ }^{89}$ It is interesting that nobody protested or complained about this practice, but this is related to the thorny topic of power and authority and merits further investigation elsewhere due to limited space in this article.

It seems corporal punishment was perhaps more gendered than any other pun-

85 Italics added by the authors. This statute was coined mainly for primary school (kansakoulu), but it related to other schools as well and added to the previous act of 1872 regarding secondary schools only: AA, June 6, 1914 ("muuttamalla ja täydentämällä asiaa koskevia säädöksiä, kieltää ruumiillisen kurituksen käyttämisten kurinpitokeinona valtion ylläpitämissä ja kannattamissa oppilaitoksis$\left.s a^{\prime \prime}\right)$.

86 Kiuasmaa 1982, 128. "[A]setus ei muodostunut kuitenkaan esteeksi vielä myöhemminkin kotona annetulle kuritukselle, joka koulussa voitiin hyväksyä jonkin muun ja ilmeisesti varsin ankaran rangaistuksen korvaukseksi"

87 Puranen, doctoral dissertation manuscript, forthcoming.

88 The 1965 statute for secondary schools actually mentions that punishment no. 7 (expulsion) can be aborted if "parents immediately reprimand the pupil so that a noticeable improvement in conduct can be seen" ("[...] vanhemmat heti oikaisevat oppilasta niin, että nähtävä parannus on tapahtunut, voidaan rangaistuksesta luopua"). See Ragnar Meinander and Toivo Aattonen, Oppikoulun hallinto (Helsinki: WSOY, 1965), 104; Kiuasmaa (1982), 527.

89 Erkki Onikki, Opetustoimi: Eripainos Suomen Laki II -teoksesta 1972 (Helsinki: Valtion painatuskeskus, 1972). 
ishment..$^{90}$ It seems girls were not sent home to be corporally punished, and we found no stories about teachers punishing their female pupils in any of the informal accounts written about life in these schools. This correlates with a few earlier studies on the general implementation of punishment practices in schools. Saara Tuomaala suggests that teachers in Finnish primary schools were more likely to physically punish male pupils, and that girls generally received less harsh punishments. ${ }^{91}$ Meanwhile, Aksel Rosenqvist, an educationalist at the time, stated that boys needed tougher discipline, as it was "character-forming" for boys, but by the same argument it was dangerous to do this to girls in case it made them too "masculine." ${ }^{92}$ Corporal punishment was nevertheless used in "reformatory schools" for delinquent girls. ${ }^{93}$ Clearly the harsher punishment regimes in these schools was because the girls were already considered to be delinquent in some way. Comparing the disciplinary practices of these schools with those in primary and secondary schools is thus unhelpful. This relates, for instance, to various contextual expectations of people coming from different backgrounds.

It is now time to turn to an additional layer of supplementary evidence, provided by various informal historical and oral accounts of school life. These testify to the wider use of corporal punishment in general. ${ }^{94}$ Several memoirs of former secondary school pupils contain stories of teachers that carried out a variety of corporal punishments in the early twentieth century. ${ }^{95}$ According to these memoirs, teachers who were most likely to rely on corporal punishment rarely sent their pupils to detention or school jail. As one writer notes that one such teacher, called Nordin, just "did not do detention." ${ }^{96}$ It is worth noting from these examples that a clip "over the lughole"97 was probably, by many contemporaries, not considered to be violent. Indeed, there

90 The use of corporal punishment was not allowed in girls' schools under any circumstances, though allowed in boys' schools: see Sisko Wilkama, Naissivistyksen periaatteiden kehitys Suomessa 1840-1880-luvuilla: Pedagogis-aatehistoriallinen tutkimus (Helsinki: Suomen historiallinen seura, 1938), 46-47.

91 Tuomaala (2004), 324-28.

92 Sinikka Aapola, "Murrosiän lyhyt historia Suomessa," in Nuoruuden vuosisata: Suomalaisen nuorison historia, ed. Sinikka Aapola and Mervi Kaarninen (Helsinki: Suomalaisen kirjallisuuden seura, 2003), 87-105. Jauhiainen (2009) confirms this approach, and mentions that the dichotomy was also brought up when contemporaries discussed coeducational schooling, see Annukka Jauhiainen, "Erillinen vai yhteinen koulu?: Yhteiskasvatuskeskustelun sukupuolittunut toimijuus," in Sukupuoli ja toimijuus koulutuksessa, ed. Hanna Ojala, Tarja Palmu and Jaana Saarinen (Tampere: Vastapaino, 2009), 122-23.

93 Vehkalahti (2008), 149-162. Some girls in these schools were also punished with school jail.

94 Pupils did not necessarily approve if an otherwise diligent pupil, but with "limited intelligence" was punished with a ferule, E. A. Aaltio, "Koulukuri, toverikuri ja pennalismi Jyväskylän yläalkeiskoulussa ja alkeisopistossa," in Jyväskylän Lyseon satavuotishistoria 1858-1958 ja juhlajulkaisu, ed. Päivö Oksala et al. (Jyväskylä: Oy Sisä-Suomen kirjapaino, 1958), 321-22. Martti Salmi, "Lyseo ja lyseolaiset 1920-luvulla," in "Oi niitä aikoja": Tarinoita ja tapahtumia Vaasan lyseon eri vuosikymmeniltä, ed. Markku Rintanen (Vaasa: Vaasan lyseon entiset oppilaat ry., 2000), 57.

95 “Pätkä Did Not Do Detention” (Jälki-istuntoja Pätkä ei harrastanut), see Salmi (2000), 57.

96 "Nordin ei harrastanut jälki-istuntoa," see Armas Mikkonen, "Muistelmia voimistelu- ja urheiluoloista Tampereen Realilyseossa v 1900 tienoilla," in Tampereen lyseo 1884-1934: Muistojulkaisu, ed. Kaarlo Nieminen (Tampere: Tampereen lyseo, 1934), 115. Nordin did in fact issue also numerous detentions, see Puranen (forthcoming). This highlights the fact that oral history sources might emphasise more subjective accounts.

97 Quite a literal translation for korvapuusti in Finnish (also the name of a bun). 
were even a few educationalists that recommended use of the rod as late as the $1920 \mathrm{~s}$. These views emphasise, however, that the punishment was supposed to be given in a "fatherly way with caution," never in anger, by slapping the bottom of the pupil with a rod. ${ }^{98}$

Interestingly, these informal accounts reveal that corporal punishment was, particularly among pupils in upper secondary school, seen as a suitable punishment for younger pupils rather than themselves. This is borne out, not only by the fact the offenders in table 2 are all first-years or younger, but also the following history from the Lyceum in Jyväskylä. A teacher had threatened first-year pupils in upper years in secondary school with corporal discipline in 1869. The pupils in the upper years at the school discussed this a meeting, and came to conclusion that it was not suitable for a regular teacher to use this kind of punishment on the upper secondary school pupils that were almost adults. They described corporal punishment as suitable for "children," and so it was "shameful" for them to be corporally punished in this way with such childish punishment method. ${ }^{99}$

This is consistent with the instances in table 2, as all those boys were most likely considered too young for school jail, which was a punishment thought more suitable for older boys. As pupils were punished with school jail and corporal punishment for the same kind of offences, these punishment methods are, in a way, comparable. In the 1872 act, however, corporal punishment corresponds more to (vii) "advice to leave" (which was effectively like expelling the pupil).

In the larger contextual frame, we would describe the practice of chastisement as a form of liquid violence that slops back and forth (or is at least easily transferable) between the public and private domains, straddling as it does the nexus between them. Starting with an offence at school, a punishment is issued, to be delivered at home, and/or vice versa-parents give their assent for a punishment to be administered there. Thus, a violent corporal punishment is carried out, one way or another, in the name of discipline. In general, the practice of chastisement was still very common at home, and it was even expected in the upbringing of boys. ${ }^{100}$ This proves, at least to some extent, that the process of discipline was not as straightforward as most contemporary educationalists (and the previous works using these as primary sources) have suggested.

\section{Conclusion}

As we have shown in this article, despite the regulations and recommendations of educationalists at the time, many punishments were still carried out in Finnish secondary schools at the turn of the twentieth century. We found more than 3500 instances in the punishment records that we examined as part of our exploratory case-study of

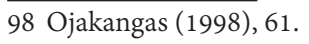

99 However, the pupils would have allowed the headteacher of the school to punish them physically, see Oksala et al. (1958), 322-234.

100 Kemppainen (2001), 60-63; Ojakangas (1998), 61; Ann-Catrin Östman, "Rakkaus ja patriarkaalisuus ahtaassa yhteisössä: Mieheys kansanomaisessa kehyskertomuksessa" in Näkymätön sukupuoli: Mieheyden pitkä historia, ed. Pirjo Markkola, Ann-Catrin Östman and Marko Lamberg (Tampere: Vastapaino, 2014), 164-165. The practice of chastisement was banned as late as 1983 in Finland, see for instance Hytönen et al. (2016). See also Eilola and Valtonen (2014) for a more detailed introduction to the twentieth century history of the practice in Finland. 
three geographically representative schools. This indicates a more gradual change in punishment practices than has been previously assumed in scholarly works based on more normative sources, or in those focusing on school as a disciplinary institution. Moreover it supports our argument, and also those of Cowen and Rappleye's, that a more empirical, critical, and historical approach to the history of education would add greatly to existing knowledge in the field. It also seems quite hard to believe that punishments were only used as a last resort.

These could still represent an exception, but the selection of three schools, from different regions and different yet comparable forms (coeducational, lyceum, and girls' school) - and supplemented with subjective histories from informal accounts-makes this quite unlikely. Although the subjective accounts should be seen in terms of the oral history tradition and therefore as somewhat "anecdotal" or limited, the fact that physical violence and discipline feature time and time again in former pupils' accounts is enough to merit further enquiry. There is a need for further research that uses previously overlooked sources, such as punishment records from elsewhere. Equally, the results of previous works need to be reassessed in the light of these new sources, even if the latter contradict what has previously been assumed. Not only have we found that numerous punishments were issued, but that some of them went against the various regulations, norms, and recommendations of the time. Detention, for instance, was used to such extent that it appears to have gone against the original recommendations that it be used only in exceptional cases. In addition, incarceration (a far harsher punishment than detention) was still in use, and there were even instances when corporal punishment was officially recorded as having been administered via the fluid practices of chastisement. These already provide valid grounds for reassessing previous literature that has not fully taken into account how gradual the actual change in punishment practices was.

However, even though the number of overall punishments issued in our three schools was rather high, the number of corporal punishments was lower than we expected. Punishments were clearly gendered, especially corporal punishment. Altogether we only found four cases of corporal punishment, and none of them involved female pupils. The School Order Act of 1872, and the regulatory changes that followed, made corporal punishment in school illegitimate and yet, as we have seen, there were ways around this.

In each of the four cases, the pupil was sent home to receive his "outsourced" corporal punishment as mentioned above. This does not take the school out of the equation though, as it was the school that usually instigated the process in the first place (even if in one case a father actually suggested to the school that he punish his son). The school also supervised and even recorded the punishment. Thus, these schools did, at least to some extent, also rely on corporal punishment. As our cases show, corporal punishment was chosen to avoid the far worse scenario that a pupil asked to leave instead. Corporal punishment was also seen as a punishment suitable for younger children who were too young to be incarcerated.

However, we cannot make a valid generalisation based on these four cases along the lines of our initial hypothesis. The low number of directly applicable instances does not yet adequately testify to lingering practices of corporal punishment. These four cases could well have been exceptions, for instance, and they anyway make up a very small proportion of all the punishments handed out. There could be many 
reasons for these limited findings. One is that recording corporal punishment was something that was now being frowned upon and was, at least publicly, not recommended; another, illustrated by the informal school histories indicate that many instances of corporal punishment were more of a reaction than something that was systematically planned. There is also the matter of there having been very few means, formal and informal, for a pupil to complain about such punishments, especially because corporal punishment was still tolerated in the private sphere. As such it could be seen as a liquid form of violence, able to slip between spheres and settle into each appropriate situation.

When we compare our study to previous works based on a much larger number of sources, our educated guess is that our limited findings are perhaps just the tip of an iceberg. ${ }^{101}$ This is also supported to some extent by the high overall number of punishments issued and the accompanying informal accounts. Practices and cultures tend to change gradually and this is confirmed by the high number of punishments in total. It might also still apply to corporal punishments, as it is quite possible that the continuing practice of patriarchal chastisement might have affected our findings and this merits further research. Revealing at home that one had been punished physically, might have led to additional repercussions at home due to the social, structural and cultural norms in which school and teachers had certain prerogatives and a recognised social position.

In conclusion, one can safely say that the ideals and recommendations of avoiding punishment altogether were not quite yet an everyday reality: the number of punishments remained high well after the School Order Act of 1872, and other normative sources would imply. The sheer quantity of punishments reveals that the goals regarding them set in the normative sources were simply not met. Indeed, teachers, most of whom who had been trained to incorporate punishment in their repertoire or had experienced punishments during their time as pupils themselves, were not going to give up certain prerogatives so easily. In this sense, our hypothesis that the culture of corporal violence lingered for some time is still worth pursuing in further research. If punishments continued to be issued in general, then perhaps traces of corporal punishment (and violence) can be found. A totally different matter is, whether some of the forms of "legitimate" punishment could already be counted as violence, too. This, however, needs to be addressed in detail elsewhere. For now, the definition of violence as a descriptive term provides a starting point for further research.

Punishment records certainly contribute to making sense of the history of education. The case study provided in this article indicates there remains a need to reevaluate the wider context of possible violence in punishment practices, and to see whether the practice of corporal punishment in schools was really a rare occurrence or not.

101 Karoliina Puranen, the first author of this article considers these matters in greater detail in her ongoing doctoral dissertation research, which is intended for completion in 2019. 


\section{References}

Archival primary sources

Finnish National Archives

The Archives of Jyväskylä Lyceum (Jyväskylän lyseon arkisto)

Rangaistuskirjat (Punishment records)

II Ae:1, 1898-1905

Opettajainkokousten pöytäkirjat (Minutes of teachers meetings)

II Ca:2, 1860-1921

Tarkastuspöytäkirjat (School inspection records)

II Cb:9, 1875-1973

Kuopion yhteiskoulun arkisto (The Archives of Coeducational school of Kuopio)

Rangaistuspäiväkirjat (Punishment records)

Ad:1, 1898-1901

Ad:2, 1901-1906

Opettajainkokousten pöytäkirjat

Ca:1, 1897-1915

Tarkastuspöytäkirjat

Cb:1, 1904-1937

Tampereen tyttölyseon arkisto (The Archives of Girls' school of Tampere)

Rangaistuskirjat

Ae:1, 1893-1920

Opettajainkokousten pöytäkirjat

Ca:1, 1893-1949

Tarkastuspöytäkirjat

Cb:1, 1902-1974

\section{Printed sources}

Tamminen Dahlman, Anne, Lahtinen, Matti \& Vehkamäki, Pirjo. Julkisuus ja tietosuoja opetustoimessa: Opas koulujen ja oppilaitosten käyttöön. Tampere: Opetushallitus, 2013.

Meinander, Ragnar \& Aattonen, Toivo. Oppikoulun hallinto. Helsinki: WSOY, 1965. Onikki, Erkki ed. Opetustoimi: Eripainos Suomen Laki II -teoksesta 1972. Helsinki: Valtion painatuskeskus, 1972.

Statute Book of Finland, (HKMNG: Hans Kejserliga Majestäts Nådiga Gymnasie- och Skol-Ordning fär Storfurstendömet Finland), November 6, 1843.

Statute Book of Finland, (KMAKS: Keisarillisen Majesteetin Armollinen Koulujärjestys Suomen Suuriruhtinaanmaalle), August 8, 1872, no. 26.

Statute Book of Finland, (AA: Armollinen Asetus, jolla ruumiillisen rangaistuksen käyttäminen oppilaitoksissa kielletään), June 6, 1914, no. 24.

\section{Other primary printed sources}

Aaltio, E. A. "Koulukuri, toverikuri ja pennalismi Jyväskylän yläalkeiskoulussa ja alkeisopistossa." In Jyväskylän Lyseon satavuotishistoria 1858-1958 ja juhlajulkaisu, edited by Päivö Oksala et al., 321-47. Jyväskylä: Oy Sisä-Suomen kirjapaino, 1958. 
Alkio, Paavo. “Koulumuistoja Vaasan lyseosta." In Vaasan lyseo 1880-1980, edited by Alpo K. Rapila, 262-270. Vaasa: Vaasan lyseon entiset oppilaat, 1980.

Haavio, Jaakko. Mennyttä aikaa muistelen. Helsinki: Kirjapaja, 1972.

Hannula, Seppo. Kuopion yhteiskoulun vaiheet 1892-1967. Kuopio, 1967.

Mikkola, Eero, ed. Jyväskylän lyseo 1858-1983. Jyväskylä: JYLY, 1983.

Mikkonen, Armas. "Muistelmia voimistelu- ja urheiluoloista Tampereen Realilyseossa v 1900 tienoilla." In Tampereen lyseo 1884-1934: Muistojulkaisu, edited by Kaarlo Nieminen, 115-118. Tampere: Tampereen lyseo, 1934.

Oksala, Päivö, ed. Jyväskylän Lyseon satavuotishistoria 1858-1958 ja juhlajulkaisu. Jyväskylä: Oy Sisä-Suomen kirjapaino, 1958.

Salmi, Martti "Lyseo ja lyseolaiset 1920-luvulla." In "Oi niitä aikoja": Tarinoita ja tapahtumia Vaasan lyseon eri vuosikymmeniltä, edited by Markku Rintanen, Olavi Oksanen, Aatto Wuorenlinna and Veikko Vörlund, 53-62. Vaasa: Vaasan lyseon entiset oppilaat ry., 2000.

Turja, Ilmari. "Sotavuosien lyseo." In Vaasan suomalainen lyseo 1880-1930, edited by Artturi Järviluoma, 142-54. Vaasa: Vaasan kirjapaino, 1930.

\section{Literature}

Ahlbäck, Anders. Soldiering and the Making of Finnish Manhood: Conscription and Masculinity in Interwar Finland, 1918-1939. Turku: Åbo Akademi University, 2010.

Ahonen, Sirkka. “Millä opeilla opettajia koulutettiin??" In Valistus ja koulunpenkki: Kasvatus ja koulutus Suomessa 1860-luvulta 1960-luvulle, edited by Anja Heikkinen and Pirkko Leino-Kaukiainen, 239-52. Suomen Kasvatuksen ja koulutuksen historia II. Helsinki: Suomalaisen Kirjallisuuden Seura, 2011.

Buchardt, Mette, Pirjo Markkola, and Heli Valtonen. "Introduction: Education and the Making of the Nordic Welfare States." In Education, State and Citizenship, edited by Mette Buchardt, Pirjo Markkola, and Heli Valtonen, 7-30. NordWel Studies in Historical Welfare State Research (4). Helsinki: University of Helsinki, 2013.

Caruso, Marcelo. "Order Through the Gaze: A Comparative Perspective of the Construction of Visibility in Monitorial Schooling (German States-Spain, approx. 1815-1848)." Encounters on Education 9, no. 2 (2008), 147-72.

Charmaz, Kathy. "Grounded Theory as an Emergent Method." In Handbook of Emergent Methods, edited by Sharlene Nagy Hesse-Biber and Patricia Leavy, 155-72. New York : Guilford Press, 2008.

Cowen, Robert. "Comparing Futures or Comparig Pasts?" Comparative Education 36 , no. 3, (2000),333-42.

Eilola Jari and Heli Valtonen. "Perheen sääntely modernisoituvassa Suomessa." In Kansallisten instituutioiden muotoutuminen - Suomalainen historiakuva Oma Maa - kirjasarjassa 1900-1960, edited by Petri Karonen and Antti Räihä. Suomalaisen Kirjallisuuden Seura 2014.

Foucault, Michel. Discipline and Punish: The Birth of the Prison. London: Penguin Books, 1977.

Glaser, Barney and Anselm Strauss. Discovery of Grounded Theory: Strategies for Qualitative Research. Routledge, 1999.

Halila, Aimo. Suomen kansakoululaitoksen historia 1: Kansanopetus ennen kansakoulua ja kansakoululaitoksen synty. Porvoo, Helsinki: WSOY, 1949. 
Husso, Marita, Helena Hirvonen, and Marianne Notko. "From Rejection to Understanding: Towards a Synthetic Approach to Interpersonal Violence." In Interpersonal Violence: Differences and Connections, edited by Marita Husso, Tuija Virkki, Marianne Notko, Helena Hirvonen and Jari Eilola, 227-33. London/New York: Routledge, 2017.

Husso, Marita, Tuija Virkki, Helena Hirvonen, Jari Eilola, and Marianne Notko. "A Spatial-temporal, Intersectional and Institutional Approach to Interpersonal Violence." In Interpersonal Violence: Differences and Connections, edited by Marita Husso, Tuija Virkki, Marianne Notko, Helena Hirvonen and Jari Eilola, 1-13. London/New York: Routledge, 2017.

Husso, Marita, Tuija Virkki, Marianne Notko Helena Hirvonen, and Jari Eilola. eds. Interpersonal Violence: Differences and Connections. London/New York: Routledge, 2017.

Hytönen, Kirsi-Maria, Antti Malinen, Paula Salenius, Janne Haikari, Pirjo Markkola, Marjo Kuronen, and Koivisto, Lastensuojelun sijaishuollon epäkohdat ja lasten kaltoinkohtelu 1937-1983. Helsinki: Sosiaali- ja terveysministeriön raportteja ja muistioita 2016.

Jalava, Marja. “Kansanopetuksen suuri murros.” In Valistus ja koulunpenkki: Kasvatus ja koulutus Suomessa 1860-luvulta 1960-luvulle, edited by Anja Heikkinen and Pirkko Leino-Kaukiainen, 74-94. Suomen kasvatuksen ja koulutuksen historia II. Helsinki: Suomalaisen Kirjallisuuden Seura, 2011.

Jauhiainen, Annukka. "Erillinen vai yhteinen koulu?: Yhteiskasvatuskeskustelun sukupuolittunut toimijuus." In Sukupuoli ja toimijuus koulutuksessa, edited by Hanna Ojala, Tarja Palmu and Jaana Saarinen, 101-35. Tampere: Vastapaino, 2009.

Johansson, Ulla and Christina Florin. "The Trinity of State, Church and School in 19th Century Sweden." In Polish and Swedish Schools in the 19th and 20th Centuries: A Historical Study, edited by Ryszard Kucha and Ulla Johansson, 63-76. Lublin: Maria Curie-Sklodowska University Press 1995.

Kaarninen, Mervi. "Oppikoulu yhteiskunnan rakentajana." In Valistus ja koulunpenkki: Kasvatus ja koulutus Suomessa 1860-luvulta 1960-luvulle, edited by Anja Heikkinen and Pirkko Leino-Kaukiainen, 405-29. Suomen kasvatuksen ja koulutuksen historia II. Helsinki: Suomalaisen Kirjallisuuden Seura, 2011.

Kemppainen, Jaana. Kotikasvatus kolmessa sukupolvessa. Jyväskylä: University of Jyväskylä, 2001.

Kiuasmaa, Kyösti. Oppikoulu 1880-1980: Oppikoulu ja sen opettajat koulujärjestyksestä peruskouluun. Oulu: Pohjoinen, 1982.

Landhal, Joakim. "The Eye of Power(-lessness): On the Emerge of the Panoptical and Synoptical Classroom." History of Education 42, no. 6 (2013), 803-21.

Larsson, Esbjörn. En lycklig Mechanism: Olika aspekter av växelundervisningen som en del av 1800-talets utbildningsrevolution. Uppsala: Opuscula Historica Upsaliensia, 2014.

Larsson, Germund. Förbrytelser och förvisningar: Bestraffningssystemet $i$ de svenska läroverken 1905-1961. Uppsala: Uppsala University, 2018.

Launonen, Leevi. Eettinen kasvatusajattelu suomalaisen koulun pedagogisissa teksteissä 1860-luvulta 1990-luvulle. Jyväskylä: Jyväskylän yliopisto, 2000.

Lidman, Satu, Anu Koskivirta, and Jari Eilola, eds. Historian tutkimuksen etiikka. Helsinki: Gaudeamus, 2017. 
Margolis, Eric and Sheila Fram. "Caught Napping: Images of Surveillance, Discipline and Punishment on the Body of the Schoolchild." History of Education 36, no. 2 (2007), 191-211.

Meinander, Henrik. Towards a Bourgeois Manhood: Boys' Physical Education in Nordic Secondary Schools 1880-1940. Helsinki: The Finnish Society of Sciences and Letters, 1994.

Noguera, Pedro A. "Schools, Prisons, and Social Implications of Punishment: Rethinking Disciplinary Practices." Theory Into Practice 42, no 4 (2003), 341-50.

Norlin, Björn. "School Jailhouse: Discipline, Space and the Materiality of School Morale in Early-Modern Sweden.” History of Education 45, no. 3 (2016), 263-84.

Ojakangas, Mika. Lapsuus ja auktoriteetti: Pedagogisen vallan historia Snellmanista Koskenniemeen. Tutkijaliiton julkaisu 85. Helsinki: LIKE, 1998.

Peltonen, Matti. Matala katse: Kirjoituksia mentaliteettien historiasta. Tampere: Hanki ja jää, 1992.

Puranen, Karoliina. Kiltit tytöt, vilkkaat pojat?: Sukupuoli ja koulukuri 1800-1900-lukujen vaihteen oppikouluissa. Jyväskylä: University of Jyväskylä, 2015. http://urn.fi/URN:NBN:fi:jyu-201506012117.

Rantala, Jukka. "Oppikoulunopettajat." In Valistus ja koulunpenkki: Kasvatus ja koulutus Suomessa 1860-luvulta 1960-luvulle, edited by Anja Heikkinen and Pirkko Leino-Kaukiainen, 304-11. Suomen kasvatuksen ja koulutuksen historia II. Helsinki: Suomalaisen Kirjallisuuden Seura, 2011.

Rappleye, Jeremy. Educational Policy Transfer in an Era of Globalization: TheoryHistory-Comparison. Komparatische Bibliothek, Volume 23. Frankfurt am Main, Peter Lang, 2012.

Sandin, Bengt. Hemmet, gatan, fabriken eller skolan: Folkundervisning och barnuppfostran i svenska städer 1600-1850. Lund: Arkiv, 1986.

Stugu, Ola Svein. "Educational Ideals and Nation Building in Norway 1840-1900." In The Nordic Lights: Education for nation and Civic Society in the Nordic Countries, 1850-2000, edited by Sirkka Ahonen and Jukka Rantala, 107-22. Helsinki: Finnish Literature Society, 2001.

Strömberg, John. "Oppikoulun laajentuminen ja yhtenäistyminen." In Valistus ja koulunpenkki: Kasvatus ja koulutus Suomessa 1860-luvulta 1960-luvulle, edited by Anja Heikkinen and Pirkko Leino-Kaukiainen, 120-139. Suomen kasvatuksen ja koulutuksen historia II. Helsinki: Suomalaisen Kirjallisuuden Seura, 2011.

Tegborg, Lennart. Folkskolans sekularisering 1895-1909: Upplösning av det administrativa sambandet mellan folkskola och kyrka i Sverige. Acta Universitatis Upsaliensis, Studio Historico-Ecclesiastica Upsaliensia 14. Uppsala/Lund: Föreningen för undervisningshistoria, 1969.

Tuomaala, Saara. Työtätekevistä käsistä puhtaiksi ja kirjoittaviksi: Suomalaisen kansakoulun ja maalaislasten kohtaaminen 1921-1939. Helsinki: Suomalaisen Kirjallisuuden seura, 2004.

Tuomaala, Saara. "Kamppailu yhteisestä koulusta ja oppivelvollisuudesta." In Valistus ja koulunpenkki: Kasvatus ja koulutus Suomessa 1860-luvulta 1960-luvulle, edited by Anja Heikkinen and Pirkko Leino-Kaukiainen, 95-110. Suomen kasvatuksen ja koulutuksen historia II. Helsinki: Suomalaisen Kirjallisuuden Seura, 2011.

Vehkalahti, Kaisa. Daughters of Penitence: Vuorela State Reform School and the Construction of Reformatory Identity, 1893-1923. Turku: University of Turku, 2008. 
Wilkama, Sisko. Naissivistyksen periaatteiden kehitys Suomessa 1840-1880-luvuilla: Pedagogis-aatehistoriallinen tutkimus. Helsinki: Suomen Historiallinen Seura, 1938.

Östman, Ann-Cartrin. "Rakkaus ja patriarkaalisuus ahtaassa yhteisössä: Mieheys kansanomaisessa kehyskertomuksessa." In Näkymätön sukupuoli: Mieheyden pitkä historia, edited by Pirjo Markkola, Ann-Catrin Östman and Marko Lamberg, 159-73. Tampere: Vastapaino, 2014. 